\title{
Preschoolers' use and exploration of concepts related to scientific phenomena in preschool
}

\author{
Annika Åkerblom', Kristina Thorshag²
}

\begin{abstract}
The study described in this paper concerns science education in preschool, more specifically how young children in preschool settings invent, develop and explore science and scientific concepts in problem-solving and communicative situations. The aim of the paper is to discuss young children's concept creation and draw conclusions for early science education. The method used was a secondary analysis of empirical material drawn from three previous studies carried out by the authors. Examples of preschool children's use of language were extracted and was, for the purpose of this study, analyzed with a new focus on children's use of concepts. The re-analysis draws from Vygotsky's theoretical framework on children's conceptual development and appropriation of new concepts (Vygotsky, 1934/1999; Åkerblom, 2011) and from the later Wittgenstein (1986) on the role of language meaning in understanding. The findings underline the importance of allowing preschool children to invent, develop and explore science and technology concepts, as well as implications for preschool teachers to create dialogic spaces for the children to do so. The limitations of the study are however that it is based on a limited number of examples and even though it can give implications and point out directions, is not conclusive and should be followed by further research.
\end{abstract}

\section{Article History}

Received: 20 July 2021

Accepted: 27 November 2021

\section{Keywords}

Preschool; Early science

Making sense; Concept

creation

\section{Introduction}

An important reoccurring issue in ECEC concerns how to make it possible for young children to make sense of basic science. In particular, one domanin emphasized in the curriculum involves supporting and developing children's understanding of concepts in natural sciences (eg. Fleer, 2009; Gomes \& Fleer, 2018; Siry \& Kremer, 2011). Policy-documents in science education internationally emphasize that there is a large value in teaching science to children already in preschool (Siry \& Gorges, 2020). In the Swedish curriculum for preschool (Curriculum for the preschool [Lpfö 18], 2018) and the educational programme for preschool class (Curriculum for the compulsory school, preschool class and school-age educare [Lgr $11], 2018)$ there are goals that aim to contribute to children's abilities to express scientific knowledge in different ways. Furthermore, the children in preschool class and preschool should be supported to develop abilities to discuss, ask questions about and explore scientific phenomena and technology processes. However teaching children about scientific knowledge, actualizes a dilemma, since scientific explanations and procedures both have to be presented in a form that makes experiential sense to preschoolers but is at the same time true to scientific knowledge (Åkerblom et al., 2019). Another important issue is the role that science concepts play, both as they are invented by children themselves in their attempts to make sense of the world around them; in addition to the way in which preschool teachers teach about scientific concepts. It is, however not clearly stated in the goals if, how, or for what purpose the preschool teachers should teach scientific concepts to the children.

The research literature on early science and technology point to the value of providing young children with opportunities to engage in science and technology (eg. Fleer, 2009; Fleer \& Pramling, 2015;

\footnotetext{
${ }^{1}$ Gothenburg University, Faculty of Education, Department of Education, Communication and Learning, Gothenburg, Sweden, e-mail annika.akerblom@gu.se, ORCID https://orcid.org/0000-0003-4125-9775

${ }^{2}$ Gothenburg University, Faculty of Education, Department of Education, Communication and Learning, Gothenburg Sweden, e-mail kristina.thorshag@gu.se ORCID: https://orcid.org/0000-0003-4742-783X
} 
Mawson 2010; Milne \& Edwards 2011; Robbins 2005; Rogers \& Russo 2003;Siry, 2013; ). In a longitudinal study that explored early science experiences in preschool, Saçkes et al. (2011) suggested that availability of science materials and time to explore those facilitated children's participation in science activities. However, the results of the longitudinal study also indicated that those early science experiences were not predictive for the children's later science achievements in school (ibid.). The results could be interpreted that access to learning materials and time for exploration are not the only factors that matter for children's science understanding. In a Swedish study about what shapes science activities in preschool by Sundberg et al. (2018), two factors were found to be of particular importance; the structure and educational culture of the preschool practice. When the preschool community was characterized with joint understandings of the purpose of the science activities this allowed the preschool teachers to frame the science content and support the children's science learning in child-responsive science activities. Furthermore, Fleer (2009) argues for the importance of an adult mediating science concepts to children to pay attention to in preschool settings. To be able to distinguish the scientific concepts and make scientific sense of science materials, the teacher must support the children's concept creation. Preschool children's opportunities to make scientific sense of preschool activities are closely related to the teacher's perspective on science and how they view the children's capacities for learning (Saçkes, 2014). Gomes and Fleer (2018) showed that if the teacher had a 'sciencing attitude' and could see how the affordances of the environment could enable science learning for the children.

The significance of considering the diverse ways that children express and make sense of scientific experience has been stressed by a number of researchers (eg. Åkerblom, 2015; Siry \& Gorges, 2020; Siry \& Kremer, 2011). One example was provided by Siry and Gorges (2020) who conclude, based on a study of a multilingual child, that children need to use multiple resources to express what they understand. The girl in their examination used multiple modalities, bodily language to enact her science understanding. Furthermore, dialogues with children can provide opportunity to shed light on how children conceptualize science and technology phenomena (Rogers \& Russo, 2003). Everyday conversations with children about their understanding are critical to explore how they interpret their experiences according to Siry and Kremer (2011). The authors further highlight that children should be given opportunities to share their understandings through discussions in relation to science activities (ibid.). Saçkes (2014) concludes, based on a study on children's understanding of the day and night cycle, that science teaching in preschool should be inquiry-based and playful, with hands-on activities that allow the children to be active participants in the learning environment. Pramling and Pramling Samuelsson (2011) emphasize the role of language and linguistic mediation of a child's experiences by a more competent partner, and the use of children's different understanding as a resource and as a pedagogical principle.

While the role of preschool teachers for children's learning scientific concepts are emphasized in research, there are at the same time a number of studies showing that preschool teachers have difficulties supporting young childrens conceptual development (e.g. Gomes \& Fleer, 2018, Saçkes et al., 2011; Siry \& Kremer, 2011; Tu, 2006). This may have to do with the preschool teachers lacking formal science and technology knowledge (Saçkes et al., 2011), and that preschool does not have a tradition of teaching science and technology. The gaps of knowledge acombined with the lack of tradition to teach science may create a sense of insecurity. This insecurity may also have to do with a lack of knowledge about how young children invent, develop and use science concepts in everyday preschool activitites. To illuminate these issues this study aims to contribute to the discussion of how young children use concepts through a reanalysis of empirical material of children using science/technology concepts in communicative situations in preschool settings.

The aim of the paper is to discuss young children's concept creation during exploring activities and reflection over their own language use, and to draw conclusions for early science education. The significance of this study thus lays in the potential to provide preschool teachers with insights about children's concept creation. 
Preschoolers' use and exploration of concepts...

\section{Questions:}

1. How do preschool children themselves invent basic sientific concepts?

2. How do preschool children develop basic sientific concepts?

3. How do preschool children explore basic sientific concepts?

4. How can children's concept development and scientific sense-making be supported in earlychildhood settings?

\section{Early Science in Swedish Preschool and Preschool Class}

Most Swedish children between 1-5 years attend early childhood education, or preschool as it is generally called. Swedish preschool is regulated in the National Preschool Curriculum (Lpfö 18, 2018) and the municipality is required to provide pre-schooling for all children residing in Sweden from the age of one. Preschool is voluntary but as the children turn 6 they go on to obligatory preschool class for one year, before entering compulsory school. The educational programme for preschool classes stipulates that it should '...contribute to the continuity and progression of the pupils' development and learning as well as prepare the pupils for continued education' (Lgr 11, 2018, p.19).

The educational programme for preschool class should provide education that is play-based and emanates from the child's interests. Children should be given opportunities to develop understanding of the surrounding world as well as making sense of scientific concepts (Lpfö 18, 2018). Furthermore, the curriculum states that it is the preschool teacher who is responsible to support children's attempts of making sense.

When it comes to contents such as science and technology, there are specific goals in both curricula. The goals of the preschool curriculum concern the ability to express scientific/technological knowledge in different ways. It also stipulates that children should develop their ability to discuss and ask questions about these issues. In the educational programme for the preschool class, it says that teaching should: '...contribute to the development of the pupils' interest in and knowledge of nature, technology and society, by giving them the opportunity to explore and pose questions on and discuss phenomena and relationships in the world at large.' (Lgr11, 2018, p.20). However, to be able to explore, discuss and understand science, children in preschool and preschool class need to be provided with conceptual knowledge. However, it is not clearly stated in the goals what scientific concepts preschool teachers should teach. Altogether the combination of ambitious science teaching objectives with unclear guidelines of how to organize activities and spaces for these activities constitute large challenges for preschool teachers (Nordén \& Avery 2020).

\section{Previous Research on Children Making Sense of Science and Technology - An Exploratory Literature Review}

The purpose of the exploratory literature review was to find research with relevance for preschool science education and particularly on the role of children's scientific and technological concept development in preschool contexts.

Piaget (eg. 1971, 1973) was probably one of the first scholars to show that young children had their own, often rich and creative conceptions of the world around them. Piaget (1973) also saw, through numerous interview studies where children were invited to reason about different natural phenomena, that their intuitive conceptions about different aspects of the world would often be diverse from the 'scientifically accepted' way of thinking (Saçkes, 2015b). Piaget $(1969 ; 1971 ; 1973)$ was mainly interested in finding aspects that were stable and general in children's thinking. Since then, a lot of studies have been carried out to explore children's intuitive conceptions and the way they may differ from scientifically accepted ideas (e.g. Driver \& Easley, 1978; Osborne \& Freyberg, 1985; for an overview see Duit, 2009). The results of these early studies have been known as Children's Science (Fleer \& Pramling, 2015), and for almost 30 years those studies shaped how science education was viewed and implemented (Saçkes, 2015a). In 
some of these studies children's intuitive ideas and thinking was considered as something to overcome and as obstacles to learning the 'right scientific ideas'. However other studies have been seeking answers to why the challenges to learning and teaching science to preschool children occur (Sundberg et al., 2018; Andersson et al., 2020) and obstacles to conceptualization of abstract science concepts (Güneş \& Şahin, 2020; Hobson et al., 2010; Saçkes et al., 2011; Saçkes, 2014).

The idea of children having to overcome the obstacles of alternative conceptions is in contrast to more recent research, where children's rich conceptualization is emphasized and considered important to listen to and value (e.g. Robbins, 2005; Siry, 2011; Siry \& Gorges, 2020). Siry (2011), suggests with reference to Joe Kincheloe, that science teaching in ECE should start with the assumption that even young children can produce new and creative knowledge about scientific phenomena. Consequently, the way children and their knowledge about science and technology are viewed, have large impact on how early education is organized for and related with them. When Piaget's studies were critically examined, this have opened up for a discussion about how the child was viewed in experiments and interviews (e.g. Donaldson, 1978; Hundeide, 1977; Pramling, 2006). Güneş and Şahin (2020) found in a study of five-year olds' epistemic thinking about the concept of time, using children's drawings, that in contrary to Piaget's (1969) interpretations, five-year olds could demonstrate abstract thinking in conceptualization of time. This research points at the importance of considering aspects such as the situation and discursive factors as well. Siry (2011) further claims that when children's science is studied when they interact and a with a research focus on their embodied enactment, rather than just verbal speech this can support a new view on children and their investigations as rich of resources instead of as lacking something. Furthermore, to express their understandings, young children often include a broad repertoire of multimodal and other signs so make their ideas visible (Siry \& Gorges, 2020). As an example, Kalogiannakis et al. (2018) showed in a study of preschool children's understanding of magnetism that drawing allowed the children to express their understanding of the phenomenon, and thus give their teachers an opportunity to get insight into children's thinking about magnetism. In dialogues with children around their investigations and explanations it is possible to uncover how they learn and think (Fleer \& Pramling, 2015) and when asked to reflect over the meanings of words they used in their explanations, this could provide opportunities for the children to become aware of their thinking and use of language (Åkerblom, 2011), and metaconceptual awareness, also stressed by Saçkes (2014).

Andersson and Gullberg (2014) showed that conceptions about children and their thinking abilities also have impact on how their activities and speech are interpreted. A teaching episode in preschool, with the aim of developing children's conceptual understanding about floating/sinking, was analyzed from two different analytical perspectives. When the activity was analyzed with a focus on whether the children developed their scientific thinking, the result did not indicate that they had appropriated scientific concepts or that their scientific thinking had developed. However, when the activity was viewed from a different perspective, with a focus on children's feelings as participants of a science activity, the result showed in contrast, that the activity of speaking and thinking about density had been a positive experience. So, the two analyses of the same preschool activity showed a difference in how science was constituted that was related to how the children were viewed (Andersson and Gullberg 2014). A pedagogic conclusion to draw from this research is that if children are perceived as resourceful, teaching must be based on children's experience and their conceptions as resources when developing children's thinking further.

Another way to handle the relation between children's experience and scientific concepts is to organize drama-activities and role-play to support children's abstract thinking and make science meaningful to them. According to Ødegaard (2003), the use of drama can be a way to support children's meaning making of science concepts for which they lack words, or for abstract explanations of phenomena imperceptible to the senses. In a study carried out by Åkerblom and Pramling $(2019,2020)$ dramatizing was discussed as a form of teaching chemistry concepts and processes to young children, responsive to how they make sense. Six-year old children $(n=11)$ from a preschool class were interviewed after they had participated in a workshop where they were invited to dramatize certain chemistry concepts and processes. Dramatizing was in the study understood as role play in an imaginary dimension (as if). Åkerblom and 
Preschoolers' use and exploration of concepts...

Pramling (2019) argue that central to dramatizing is how participants distinguish, relate and shift between engaging with the phenomena and the processes of 'as if' and 'as is'. Also, the way that the children spoke about their participating in the activity indicate that they have viewed themselves as agents, rather than being recipients of information.

Based on the results of a study of one pluri-lingual child's meaning making in a science activity, Siry and Gorges (2020) argue for the value of considering the richness and diversity of resources children use to make sense of science. This is especially important in multilingual preschool settings, since using nonverbal resources can facilitate communication, not only between the children, but also for teachers to gain deeper insights in meaning- making processes of children. This research underscores the claim that science education for young children should aim to create dialogic spaces where children and their teachers can negotiate and develop meanings about science phenomena and use a variety of resources to do so.

\section{Theoretical Framework}

The notion of language has different meanings in different contexts, and how language or the activity of languaging is viewed, have great impact on how teaching languages is organized and structured. How language is understood also influences the views on scientific concepts and how those are to be mastered by children. The language philosopher Wittgenstein (1953/1968) distinguished in his writings two very different ways of viewing the function of language; one view was language as a structural, focusing language as a system of meanings and the other view was language as expressive, focusing the activity of expression.

With a structural view, the main function of language is to name and describe objects and aspects in the world. Every word can be perceived as containing its meaning- the object for which the word stands. The process of learning to understand a concept means to establish the correct relationships between objects and words. The structural conception of language is in many ways in line with the common sense understanding of what language is and how language works and can also, to some extent be identified in the cognitive research tradition (e.g. Vosniadou, 1994) and in the work of Chomsky (Golumbia, 2014). From a structural perspective on language, to learn scientific concepts, the main problem to address lays in the meaning those concepts are given and the presence of alternative meanings and competing systems of meanings. From a cognitive perspective the unit of analysis is the individual and consequently the purpose of teaching is to make the child change from alternative frameworks to scientific concepts (Åkerblom, 2011).

With an expressive view, language is understood as activity of expressing something, and language meaning is seen as constituted in its use rather than something stable that exists beforehand. Language, from this perspective is seen as something open and mobile (Åkerblom, 2011). To emphasise the activity of using language, the notion of 'languaging' is often used. The notion of languaging refers to communication and includes the processes of making sense of, and shaping experience through language (Lewis et al., 2012). According to (Wittgenstein, 1953/1968), with an expressive conception of language, it is learnt during the engagement in and living in the world. Language is created and it arises in practice and could be described as both subjective (as in understanding) and intersubjective (as in communication).

When Vygotsky (1934/1999) studied the connections between language and thinking and how they were established in the child's development, word meaning was his unit of analysis. Word meaning, according to Vygotsky is at the same time both language and thinking. Appropriation of word-meaning is a complex process and starts as the child understands that there is a relation between things and words. According to Vygotsky (1934/1987) a major result of his numerous studies was the result that wordmeanings are something highly dynamic and changing.

Word meanings are dynamic rather than static formations. They change as the child develops; they change also with the various ways in which thought functions. (Vygotsky, 1934/1987, p. 217)

Vygotsky (1934/1987) saw the relation between two aspects, such as language and thinking, as in itself an activity and spoke of the activity of thinking as generalisation of concepts. According to Vygotsky conceptual development implicates phases of different generalisation. This is similar to Vygotsky's 
(1930/1995) work on imagination and creativity as the ability to combine and interpret different impressions, a mode of thinking. In Vygotsky's work the dynamic relation between two aspects were always in the fore and he used different notions to describe the aspects. His notions were sometimes overlapping and sometimes through his work used somewhat differently. Those notions have consequently been interpreted and translated in different ways (eg. Veresov, 2004). For the purpose of the present article, some of Vygotsky's concepts will be presented and used for the analysis of children's reasoning

One such distinction that Vygotsky (1935/1998) made in his work on children's concept formation, was the distinction between what he refers to as pseudo concept and concept proper. Pseudo concept implies that the child can give a number of examples of the same thing, but without necessarily being able to verbalize what these examples have in common. Concept proper, on the other hand refers to when the child is able to discern, and also express what the examples have in common so that they can be summarized under a label based on their characteristics. Another distinction made by Vygotsky (1934/1987) was between spontaneous and reflected concepts. A spontaneous concept is something drawn from children's bodily experiences with aspects of the world, and it is not reflected over. Normally in those cases, the children are not conscious of how they think, whereas reflected concepts are something the children can speak about and see as 'something'. When a concept is reflected over it gives the child opportunity to understand that this 'something' can be conceptualized in many different ways, something that opens up for learning to see differently.

Vygotsky (1934/1999) distinguishes everyday concepts from scientific concepts, and he viewed the relation between those two as particularly fruitful in relation to science education. Everyday concepts relate to children's empirical experience and the consequences that can be drawn from experience. In contrast scientific concepts are concepts with specific and socially agreed upon meanings, connected to a certain field. Vygotsky (1934/1987) also explored the relation between the sense of a word and its meaning and made a distinction between them. The meaning of a concept is according to Vygotsky closely related to what we would call the agreed on definition of a word. The sense of a word, however, can be described as the personal, creative aspect of it. It is something that 'enriches' or creates a deeper meaning, and it is depending on the context of use. Meaning and sense could further be connected to what Vygotsky spoke of as scientific and spontaneous concepts (Vygotsky, 1934/1987). A scientific concept would thus be associated with the notion of meaning and everyday concept with the notion of sense.

Vygotsky (1934/1999) emphasized the relation between everyday and scientific concepts as necessary for children's learning. Scientific concepts are those that in a meaningful way for the children can be related, but not reduced to the children's everyday experience and concepts. Vygotsky argues, much like Wittgenstein (1968) that learning to use language (for example scientific concepts) implies to play with its function, and to reflect on its meanings within an activity. New concepts must also be developed and created in activity as the child actively reflects over it while using the concept. When children's experiences meet scientific terms with specific, agreed upon and established meanings, children learn new ways to conceptualize the world and aspects of it (Vygotsky, 1934/1987). But this does not happen without some tension, since children then have to leave their spontaneous and intuitive ideas. The encounter between the child's own experience and new and scientific concepts requires active and creative elaboration of those concepts (Åkerblom, 2011).

\section{Method}

The present study consists of a secondary analysis (Sherif, 2018) of empirical material retrieved from three previous studies carried out by the authors. This particular method was selected since it was appropriate for the research objective of the present study. Since the data was originally created for different purpose, a secondary analysis was performed based on a new theoretical framework with the aim to inform new research questions (Smith, 2008). The original data consisted both of video-recordings of technology activities (Thorshag, 2019) and from dialogues with six-year-old children about physical phenomena and chemical concepts (Åkerblom, 2015; Åkerblom et al., 2019). From the empirical material, a 
Preschoolers' use and exploration of concepts...

number of examples of preschool children's use of language and conception creation were extracted. For the purpose of this study, those examples were re-analyzed with a new focus on children's use of concepts. Theoretically the re-analysis draws from Vygotsky's theoretical framework on children's conceptual development and appropriation of new concepts (Åkerblom, 2011; Vygotsky, 1934/1999) and from Wittgenstein (1953/1968) on the role of language meaning in understanding. The original studies will be shortly described below.

\section{Technology Study}

The overall aim was to study how children work and explore technology in building- and construction play in preschool (Thorshag, 2019). The activities were both planned by teachers and initiated by the children. To conduct the study and to be able to document the verbal language as well as the body language, video observations were chosen as the main tool. Field notes were taken at the observations to document gatherings before and after the activities, and to give background and context to the activities. In all 11 preschool teachers and 49 children, in the age of 4-5, participated in the study. Every preschool was visited at three occasions. The video recordings were transcribed both regarding speech and action (Heikkilä \& Sahlström, 2003)

\section{Children Making Sense of Physical Motion and Basic Astronomy}

The overall purpose of the original study was to explore, analyse and describe how children between six and 14 years old (n 64) use language to express and make sense of physical phenomena (Åkerblom, 2011). The empirical examples for the present study were drawn from dialogues with six-year-old (n 18), who all attended preschool class at the time. The children were asked questions intended to point out a problem that could be explained in classical mechanics and basic astronomy: 'What happens when a ball is thrown slantingly up in the air?' 'Why does not the moon fall down?' A dialogue structure was used to encourage the children to reflect on their use of language when explaining the process.

\section{Chemistry Study}

The study was an empirical investigation of how concept young children form chemistry concepts. 226 -year old children from one preschool class participated in a chemistry activity that was playfully enacted at a culture centre for children (Åkerblom et al., 2019). Pre-and post-interviews were carried out with the children and the activity was digitally recorded. Still pictures showing the chemistry activity and the children participating in it was made from the recording and were then used in the post-interviews to create mutual ground for talking with the children about what they remembered from the activity. They were also asked about how they understood the activity that they had participated in and what they thought the activity had intended to illustrate. The empirical material, consisting of the pre-and postinterviews was analyzed with a focus on how the children made sense of basic chemistry processes and concepts like water, molecule and chemistry (as such).

\section{Ethical Considerations}

The ethical aspects related to the original studies were handled according to current ethical principles for research (codex.vr.se). This meant that the care-takers of the children that participated in the studies had given their written consents prior to the video-recordings and interviews. The participating children were informed about the studies, that they could choose whether to participate or not, that they could interrupt their participation at any time. The researchers (who both have a background as educators for young children) were also mindful of children's body language and whether it implied that they were not comfortable being interviewed or filmed. In accordance with the ethical guidelines for research by the Swedish Research Council, every child was promised confidentiality, which meant that the names used in the excerpts are fictive.

\section{Secondary Analysis}

The analysis was carried out by the two researchers in collaboration. Each researcher selected a number of extracts from their previously transcribed empirical material, consisting of video transcriptions, 
field-notes and transcribed dialogues. The selection of excerpts to re-analyse, was done collaboratively, with the specific aim to find as rich as possible insight into the participating children's use of concepts. All the selected extracts had in common that they showed different cases of children using concepts to solve problems, explore phenomena, describe processes etc. From the first selection, seven extracts were picked out to serve as an example of a certain way of using concepts. Those examples were thematized and analyzed with a focus on children's use of concepts.

\section{Results}

In this section, the results from the re-analysis will be presented closely to excerpts from the empirical data. The findings are structured as examples of children's use of concepts and as situated in a communicative practice. Each theme is presented through one or more excerpts from the data.

\section{Invention of New Technology Concepts in Building and Construction Activities}

Example 1. The extract below from a video recording from a preschool show how four children and a preschool teacher play at the building space:

Four children and the preschool teacher Janne (J) are playing in the building space. Janne and Agnes (A) (5:6) start to construct towers with Kapla ${ }^{1}$ rods. Agnes wants to build a high tower and Janne proposes a competition about who can build the highest tower. The researcher $(\mathrm{R})$ is also participating while documenting the activity.

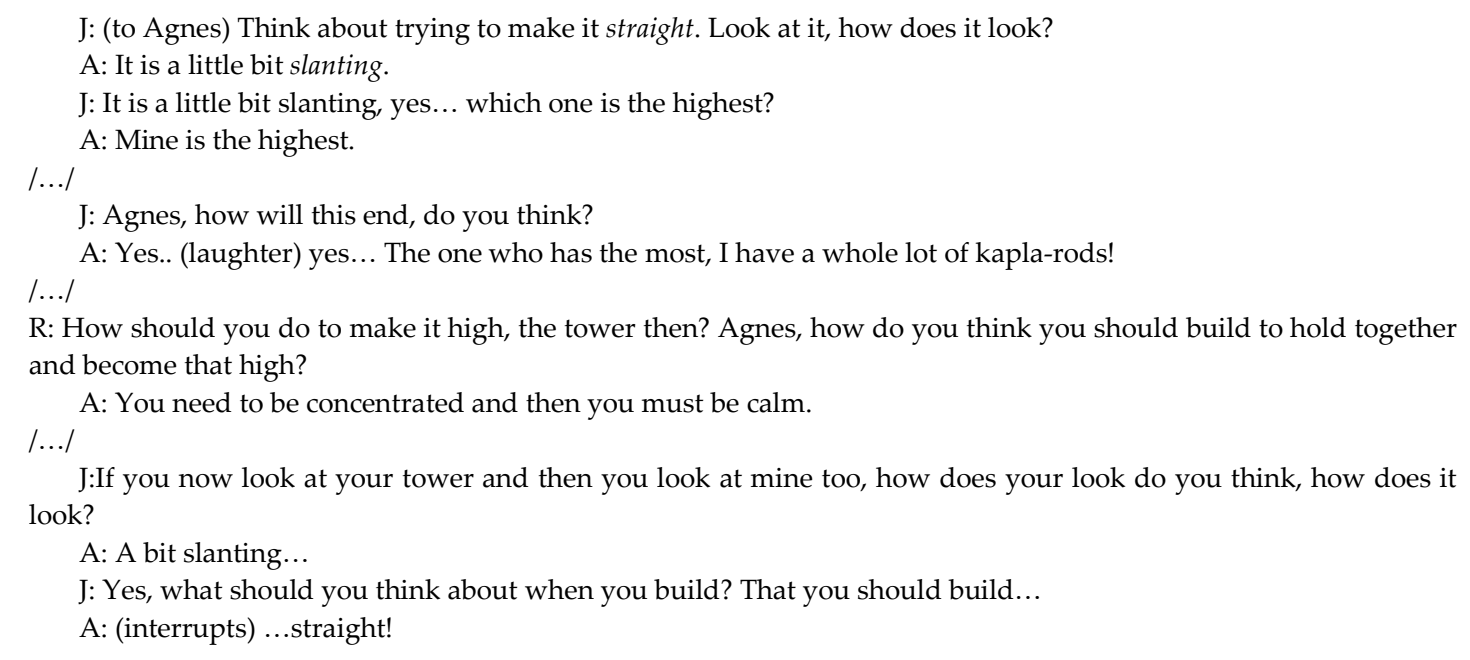

In the extract Agnes uses established and shared concepts like straight and slanting when she explains to Janne. When she looks at her first tower she can see that it is in danger to collapse and she says: 'My tower can be even higher. It can get more slanting-high!' This is her own concept slanting-high (snedhögt Sw.) to talk about a relationship, ie when the tower is tilted; it falls more easily when it gets high. Her use of the concept indicates that she is aware that to construct a stable tower, the placement of the rods and how to stack them, is critical to create a large supporting area to keep the equilibrium. Also, she is aware of that the higher the tower gets, it is a greater risk that it will collapse as the centre of gravity shifts. Slanting-high is a technical concept that she invents since she needs it for her explanation. According to Vygotsky (1934/1999) it is only when the child has understood the meaning that it needs a concept. Concepts are used for explaining or understanding something. A short while after that she has climbed the chair to continue building, the tower collapses. She starts, with enthusiasm, to build another tower and when building her third tower she stacks the rods very carefully to get her tower straight.

Example 2. David (4:3) has less experience of constructing towers with Kapla rods. He gets inspired to join in and he studies Agnes and listens to her reasoning with the teacher about the importance of equilibrium and to build carefully, adjusting the rods all the time. David puts some rods aside and the

\footnotetext{
${ }^{1}$ Kapla is a construction set consisting of identical wood planks
} 
researcher $(\mathrm{R})$ asks him why:

D: Uhh, so thick.

R: Why didn't you take those rods?

D: They are not good. You can't use them.

$\mathrm{R}$ : Why is that?

D: Because they are too thick...too fallish

A: They are too thick. Then it doesn't work, the whole construction could collapse.

Here David uses the concept fallish (rasiga Sw.) to explain to the researcher what will happen with the tower when building with rods of different dimensions. The tower gets unbalanced and the construction might collapse. David is talking about the function of the rods and he has created his own concept fallish. The meaning of this concept is shared between David and Agnes, which indicates that it is reflected over. The concept is created and connected to the activity of building to be able to communicate in the specific situation. It can be interpreted as a concept proper in Vygotsky's sense since David is able to verbalize what fallish rods have in common (that they are too thick).

Example 3. At the time of the study, an ongoing thematic work about dwellings was carried out in the preschool. In this example, three children are constructing house models. The preschool teacher introduced the children to some ideas how they could build and she presented what materials (such as ice cream sticks, flirting balls, cardboard, clothespins, rounds of juniper wood, round sticks) they could use. Tor (5:6) has decided to build a fairly large house of cardboard. When Tor starts to cut the cardboard with the small scissors for children, he has problems to get through. He tries to use both his hands but fails. After a while, he says: 'I'm not so strong with these scissors...'

His statement indicates an understanding of the function of the scissors, a two-armed lever. The larger the shears' legs, the more force there will be to cut. He needs more power to cut in the thick cardboard. The researcher then helps him to cut and they take a larger pair of scissors to help get through.

Here Tor uses the expression strong when he talks about the function of the scissors. He talks about something that corresponds to the concept of force. He does not say that the scissors are not strong, but that he does not become strong with the scissors, which shows an understanding of the tool principle and the technical content in the concept strong as Tor uses it.

\section{Using Body Enactment and Everyday Concepts for Explaining Physical Motion}

The examples under this heading are drawn from reflective dialogues where 18 children in a preschool class were asked questions intended to point out a problem that could be explained in classical mechanics and basic astronomy. The reflective dialogues were used to encourage the children to reflect on their use of language in their own explanations of what happened.

Example 4. In the sequence below, Ove (O) below was asked by the researcher (R) about what happens when he throws a ball slantingly up in the air. The researcher follows up the introducing question by asking about the reason for the ball to 'go up'.

R: What makes it go up?

O: That...I think it is the force, it has, sort of... like we take a force, as if we throw a pillow, then we have a force, as if we throw a pillow, then we have a force, and then, and so that, it just flies with that force, and then downwards...then. R: Yes?

O: Because then, then, then, it doesn't have such away-force, so just it goes down.

R: You say that it has no away-force. What is it that gives it, this away-force then?

O: I think, perhaps, here if you throw it, then maybe it, it here, so that you oouum (pointing at his arm muscle)

R: You mean that muscle...or?

O: Mm.

$\mathrm{R}$ : Aha, so it is the muscle in your arm that gives it force?

$\mathrm{O}: \mathrm{Mm}$.

R: Yes, this with force, what do you think of when you say force?

O: Force....almost nothing.

R: No? Could you have said it in another way, with another word?

O: No I can't come up with anything.

$\mathrm{R}$ : So it is what you think fits best, when we speak about throwing a ball slantingly up in the air? 
O: $\mathrm{Mm}$.

R: Yes. You said force and away-force. Is it the same kind of force?

O: Yes.

$\mathrm{R}$ : So all force is sort of away-force?

O: Yes all as if you have force to lift a table... and then you have the force here, like, and then it lifts upwards.

Ove uses the notion of force when he explains what causes the movement of a ball. The way he uses the notion can be interpreted as an everyday concept, in Vygotsky's sense. An everyday concept relates to children's empirical experience and the consequences that can be drawn from experience. In the sequence, Ove is invited to reflect on this concept that he uses as an explanation for the movement of a ball. The explanation involves the idea that force is something given (from the muscle) to an object (like a ball), and then contained within the ball, maintaining its movement, until the away-force as he puts it, ends, and the ball falls down. This idea is consistent with Ove's experience of physical movement. The notion of awayforce is his own concept, an aspect, or synonym of force. When he says that he means 'almost nothing' with force it can be interpreted that he has not reflected on his ideas. In his explanation, Ove uses, besides verbal resources, bodily and non-verbal expressions to make sense of the phenomenon.

Example 5. Evy (E) in the sequence below was asked by the researcher (R) about what happens to a ball that is thrown slantingly up in the air. Evy gets up from where she was sitting and starts to show the researcher how her understanding of how a ball starts to move, saying:

E: Yes, it goes up just because... I will show you on the floor...

R: Yes?

E: It goes up just because you do like this (mimic kicking a ball). You take it, it is so light so you can kick it, then it just flies and does what you want it to do.

Evy's explanation is almost entirely bodily when she makes sense of how the ball moves, something that applies to how Vygotsky denotes the sense of a word as the aspect that is personal, creative and something that 'enriches' meaning. The sense of a word also depends on the context where it is used. Earlier in the same dialogue when she told the researcher why she thinks that the moon is not falling down, she says that the moon is not falling because it is held by 'invisible tentacles', and in the extract below, she is asked about what she means with invisible tentacles:

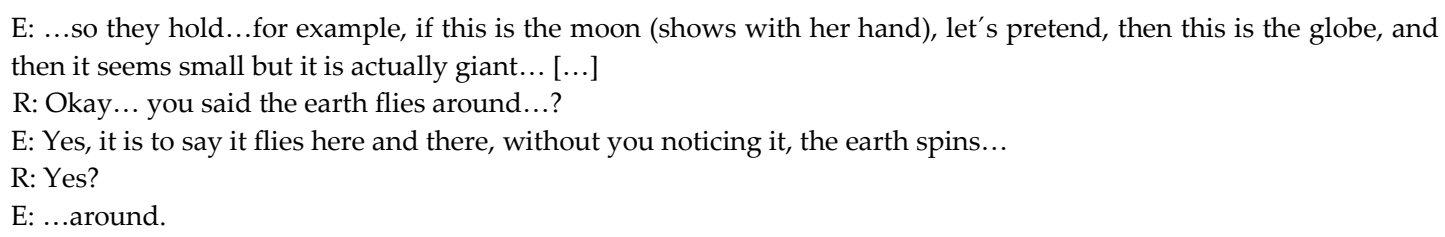

When telling the interviewer why the moon doesn't fall, Evy uses her hand to explain what she means by the metaphor of 'invisible tentacles'. Using metaphors can be seen as a way to relate something new and partly unknown, to something that is more familiar (Pramling, 2015). Also, by using the words 'let's pretend' she makes it clear that she is speaking 'as if'. This indicates that she is aware that what she says should not be interpreted literally (as is). Through those meta-markers Evy communicates about the conceptual content in terms of something that is more familiar and easier to express. Later in the same sequence she speaks about phenomena that cannot be experienced with one's senses, like the movement of the earth or the 'actual' size of the moon: She says that: 'It seems small but it is actually giant....', which implies that she is aware that the moon can be experienced differently, depending on where it is viewed from. This can be interpreted that she is aware of the difference between how it seems and how it is, something that might imply that she is on the way of appropriating an abstracted, scientific conception.

\section{Children's Reasoning and Use of Chemistry Concepts in the Space Between 'As Is' and 'As If'}

The examples below come from dialogues with children who had visited a culture centre and attended a drama activity about chemistry. The children were subsequently interviewed about what they remembered, how they had understood the activity that they had participated in and what they thought that the activity had intended to illustrate. In the dialogues, pictures from the activity were used to create mutual ground for talking with the children 
Preschoolers' use and exploration of concepts...

Example 6. In the following sequence, Kristoffer $(\mathrm{K})$ was asked by the researcher $(\mathrm{R})$ about a photo taken from above as the group of children acted as water-molecules that were mixed:

R: There, what were you doing there?

K: There we put on caps and then we became water molecules and then we pretended to be water molecules.

$\mathrm{R}:$ Yes, and what did you do then, pretending to be water molecules?

$\mathrm{K}$ : They were standing so close, in a round ring and then we were to walk around and move, room temperature, just moderately, moderately and then we walked around, around around and bounced and when we came to somebody, to glass... pane or another water-molecule, then we bounced in another direction.

Then Kristoffer is shown another picture by the researcher and asked if he can see 'what it is':

$\mathrm{K}$ : It is when they hold in a round ring, the hands, and then it is us the children who move and collide into one another and bounce away in another direction.

R: Aha. I have another Picture here, with some red hats, what was that, do you remember that?

K: Sugar molecules.

R: Do you remember why they stood that close, kind of?

$\mathrm{K}$ : Because we were, because it...the sugar molecules they keep themselves... because our water was cold and then the sugar molecules moved slowly and then, and then they keep together because a piece of sugar is built by sugar molecules and then they were a piece of sugar and all the sugar molecules and the one that it was cold water, then it sort of took long time, then it held...so that they were stuck quite a long time.

Kristoffer identifies the picture of the children wearing blue hats in terms of here 'we pretended to be water-molecules'. Using the word 'pretend' shows that he is in on the premise that this activity is characterized by imagination (as if), and because of this should not be interpreted as how something is in some sense is (as is). Kristoffer's explanation also implicates that he has made sense of the relation between movement and temperature.

Excerpt 2: In the extract below from the same dialogue, Kristoffer was shown pictures from an experiment carried out by a character acting as a chemist in the drama activity, trying to show how molecules move by pouring a coloured sugar mix in water of different temperatures. Kristoffer was and asked about what the picture was showing:

$\mathrm{K}$ : It became green.

R: And what did it mean then, when it became green?

K: That it had spread. And, it like water...the water was cold, then it becomes as a beam down, but if it was warm,

then it becomes almost like a cloud... then it becomes almost like smoke.

R: Do you know why that happened like that then?

$\mathrm{K}$ : It was because the water was warm!

$\mathrm{R}$ : Yes, you said molecule, what is a molecule?

$\mathrm{K}$ : A molecule is a small, tiny, tiny, tiny, tiny, tiny... tiny, tiny, tiny part of something.

R: Of what? What can it...

$\mathrm{K}$ : Of just anything!

When speaking about the green coloured sugar mix that is squirted into the water, Kristoffer says that if the water was cold: 'then it became like a beam down' But if it the water was warm 'then it becomes almost like a cloud... then it becomes almost like smoke'. By using everyday phenomena and observations Kristoffer speaks about something that could be difficult to explain in other terms. He uses similes like 'beam', 'cloud' and 'smoke' and meta-communicates by using markers like 'as' and 'almost like'. Those markers indicate that he is aware that what he says should not be interpreted literally (as is). Through those meta-markers Kristoffer communicates about the conceptual content in terms of something that is more familiar and easier to express. When asked about the concept of molecule (that he himself introduced earlier in the dialogue) and answering that a molecule is a small, tiny (used eight times) part of anything, he shows that he is close to appropriate a scientific understanding of one aspect of the concept of molecules, that it can be seen as the smallest particle in a chemical compound or element that has the chemical properties of that compound or element, and that it is too small to be seen. Additionally, when Kristoffer states that molecules are 'parts of anything', this could be interpreted as he is generalizing over a set of cases and uses the notion of molecule as a concept proper in Vygotsky's (1998) sense.

Example 7. In the dialogue with Carla (C) after the activity, she reflects on what she said to the researcher when asked about her conceptions of water $(\mathrm{R})$ prior to taking part in the chemistry activity. At 
that point she used the word monopoles denoting molecules.

C: I remembered that I told you the last time that it was water 'monopoles' but it was water molecules.

R: It is just water molecules that are...

C: ...no, there are sugar molecules, apart from that I don't know much more about molecules. There is a molecule in us that has been in the dinosaur, so there might be a water molecule from a dinosaur.

R: Do you remember where we can find molecules?

C: In the air, air molecules. And if water starts to boil it turns to mist that goes up in the air. They can go up there in the clouds and then they rain down.

When Carla speaks about molecules and states that she does not know more about molecules she shows that she is aware that that there might be more to know. In doing so, she has identified a learning gap, what is still not known to her. To identify learning gaps about something, can be particularly productive when trying to learn more. She understands that there are not just one, but different kinds of molecules, and she refers to as sugar molecules and air molecules, and she adds that there can be water molecules in the air as well. The way she uses the notion of molecule implicates that it is a reflected concept and that her experiences from the learning activity has supported her to appropriate the scientific concept of molecule.

Later in the same dialogue Carla was asked to reflect on the notion of chemistry, and if she knows what it means:

R: Do you know what chemistry means?

C: Chemistry is surface tension.

R: How do you mean?

C: Chemistry makes the water striders float.

$\mathrm{R}$ : The water striders float? What are water striders?

C: They are small animals living on top of the water. They have small feet and glide on the surface tension. When the surface tension disappears, they go down from the water..

Carla here answers, a bit surprisingly that chemistry is surface tension, which is consistent with an earlier experience from watching water-striders on an outing with her family. When she connects chemistry with surface tension she is making sense of previous experiences from different contexts and creates something new. This is consistent with Vygotsky's (1930/1995) view on imagination as the ability to combine and interpret different impressions, a mode of thinking. Carla's answers in this dialogue implies that she is on the way to appropriate a scientific conception of chemistry, as the study of how different substances are constructed and their properties and reactions.

\section{Findings and Discussion}

The aim of this paper was to contribute to the discussion of how preschoolers invent, develop and explore science concepts, related to preschool activities and to shed some light on how they do so. Children's conceptualization has in previous research (eg. Åkerblom, 2015; Siry \& Gorges, 2020; Siry \& Kremer, 2011) been shown to be rich, dynamic and creative when they attempt to make sense of science, and when empirical examples are viewed through a lense of Vygotsky's theorizing on concept creation, the findings can shed some light on how some pre-schoolers make sense and shape their experience through language.

The results show that children in some of the examples invent their own basic scientific concepts, like Agnes and David who are participating in an activity of building towers with building blocks, inventing concepts like 'slanting-high' for the relation between the height and inclination of a tower. When David uses the concept 'fallish' rods to explain that rods with different dimensions might cause the tower to collapse he uses a concept that is invented, but also shared by the other children taking part in the activity. When the children invent concepts they also, in addition to the use of verbal expressions, use sensory and bodily expressions, like David in the described example who shows with his body that the rod is not useful. Also, in the example when Ove shows how a ball is falling he uses bodily enactment, which have been showed by Siry (2011) as a critical aspect when children make sense of science. This example suggests that those concepts are invented by the children in the activity when they experience technology 
Preschoolers' use and exploration of concepts...

and share this experience with the other children. This is in accordance with Vygotsky's (1934/1999) insights that it is not until a child has understood its meaning that s-he will need a concept, and the concept can be expressed in any way, as long as it is shared with others. And, as the later Wittgenstein (1968) proposed, language meaning is experienced in use.

The results also show how preschoolers develop basic scientific concepts, like when Ove uses the concept of 'force' as an everyday concept (Vygotsky, 1934/1999) in his explanation to a researcher about what happens to a ball thrown slantingly up in the air. When using the concept, he relates it to his own experiences of balls being thrown and the consequences that can be drawn from his experience. The way Ove uses 'force' in a sense that is not consistent with the scientific concept, but can rather be seen as one of the steps of generalization until he will be able to use it as a scientific concept (Vygotsky, 1934/1999). Ove, like Evy in another example use, besides verbal expressions, also bodily and non-verbal expressions in the explanation. Evy shows in her explanation that she is able to distinguish between what can be experienced with the senses and a more general abstract way of conceptualizing. This is in line with other studies that show that young children often include a broad repertoire of multimodal and other signs so make their ideas visible (Åkerblom, 2015; Siry \& Gorges, 2020; Siry \& Kremer 2011).

In the empirical material, there are also examples of how preschool children explore basic scientific concepts through reasoning and reflection. In one of the examples, when Kristoffer is asked about how he experienced a drama activity about chemistry, he shows that he can distinguish between what in the activity is to be perceived as imagination - 'we pretended to be water-molecules' and what should be perceived as chemistry, the movement of molecules as an explanation of temperature. He is also using abstract metaphors and similes, indicating that those should not be interpreted literally. Also Carla reflects over the concept of molecules in relation to the experiences she made in the drama activity. The way Carla and Kristoffer are making sense of 'chemistry' and 'molecule' is consistent with Vygotsky's (1930/1995) writings on imagination as a mode of thinking and being able to combine different impressions. The way they children explore the concepts implies that they both are on the way to appropriate scientific concepts. Those findings are consistent with research by Siry and Kremer (2011) who highlight that children should be given opportunities to share their understandings through discussions in relation to science activities. Also, Pramling Samuelsson and Pramling (2011) emphasize the role of language and linguistic mediation of a child's experiences by a more competent partner, and the use of children's different understanding as a resource and as a pedagogical principle. This is also in line with several studies where the usefulness of aestetic expressions is pointed out as a way for children to explore scientific knowledge (eg. Kalogiannakis et al., 2018; Güneş and Şahin, 2020; Ødegaard, 2003).

\section{Conclusions}

To sum up, the results of this investigation show that the children's elaboration to make sense of scientific and technology concepts appear as creative and sensible. The preschoolers are forming and sharing their own concepts, as well as using disciplinary concepts for problem solving and communication. The difference between the varying contexts bring light to the situatedness of conceptualization by young children. In the study about technology the children use concepts to make their insights about building common, in dialogue with their peers or teachers. It shows that concepts are closely linked to practice are created in the activities because they fill a concrete part, to be able to share them and solve technical problems together. Whereas the dialogues about physical phenomena between children and a researcher had a different purpose, that was to reflect over their own used expressions. The form of dialogues, where the interviewer shifted between asking about physical phenomena and about the language the children had used to speak about the phenomena provided another kind of insight in the process of conceptualization.

The conclusions for how children's concept development and scientific sense-making could be supported in early childhood settings that can be drawn from this very limited study is that central to science education in preschool is that the children are afforded with rich opportunities to use disciplinary concepts and create concepts themselves to make sense of scientific phenomena. The findings are consistent 
with Vygotsky's (1934/1987) conclusions that scientific concepts are not learned in final form, but develop, and Wittgenstein (1953/1968) that language meaning cannot be formulated at a general level, until/unless it is experienced in use. This means that conceptualization and development of abstract thinking is something that is experiential first; then becomes abstract. This means that, which is also highlighted in previous research, there must be science materials available and time to explore the materials in preschool settings (Saçkes et al., 2011), but also and maybe even more critical, there must be a joint understanding among the educators about the purpose of the science activities, and they should be able to frame the science content of children's experiences in a child-responsive way (Sundberg et al., 2018). Our study, and recent research (eg. Güneş \& Şahin, 2020) also shows that children are more able to generalise and abstract scientific phenomena in a way that was previously not expected (Piaget, 1971). For the preschool teachers, a consequence of this study as stressed by Andersson and Gullberg (2014) could be that it is more important to provide a positive and permitting environment for the children, than avoiding to work with science and concepts due to lack of knowledge and insecurity.

This study contributes in particular to knowledge about children's concept creation that points at the importance that science education for preschool children should aim to create dialogic spaces where children, with the support of their teachers can invent, develop and explore science and technology concepts in a context where the phenomena are experienced.

\section{Limitations and Implication for Future Research}

Although this study has the potential to shed some light on children's conceptual development, it suffers from limitations as well. First, since the empirical material was drawn from studies with different purposes and not with the specific aim of studying children's conceptual development, the material could be difficult to analyze and information that would be interesting in relation to this study may be lacking in the material. Also, the study is very small, which means that the results are not in any way, conclusive. The way the examples were chosen, with the aim to show a rich material and examples of a variety of concept creation should be seen as examples with the purpose to discuss the matter of conceptual development. Therefore, implications for future research would be to make a larger study and to create the empirical material with the aim to answer the research questions from the beginning. For such a study, the present study could be seen as a guiding pilot study.

\section{Declarations}

Acknowledgements: Not applicable.

Authors' contributions: Both of the authors have equal contribution.

Competing interests: The authors declare that they have no competing interests.

Funding: Not applicable.

\section{References}

Åkerblom, A. (2011). Children making sense of physical phenomena. Lund University.

Åkerblom, A. (2015). Exploring the pedagogic relation: Supporting six-year olds in making sense of physical motion. Nordic EarlyChildhood Education Research, 11(6), 1-18. https://doi.org/10.7577/nbf.993

Åkerblom, A., \& Pramling, N. (2019). Dramatisering i spänningsfältet mellan som om och som är och sexåringars meningsskapande av kemiska begrepp och processer. [Dramatizing in the tension-field between as if and as is and six-year-olds' meaning making about chemical concepts and processes.] Educare-vetenskapliga skrifter, (2), 58-72. https://doi.org/10.24834/educare.2019.2.4

Åkerblom, A., \& Pramling, N. (2020). Children's understanding of representations of basic chemistry after participating in an early childhood drama pedagogical activity. Journal Of Early Childhood Education Research, 9(2), 290-313.

Åkerblom, A., Součková, D., \& Pramling, N. (2019). Preschool children's conceptions of water, molecule, and chemistry before and after participating in a playfully dramatized early childhood education activity. Cultural Studies of Science Education, 14, 879895. https://doi.org/10.1007/s11422-018-9894-9

Andersson, K., \& Gullberg, A. (2014). What is science in preschool and what do teachers have to know to empower children?. Cultural studies of science education, 9(2), 275-296. https://doi.org/10.1007/s11422-012-9439-6 
Preschoolers' use and exploration of concepts...

Andersson, K., Gullberg, A., Danielsson, A., Scantlebury, K., \& Hussénius, A. (2020). Chafing borderlands: Obstacles for science teaching and learning in preschool teacher education. Cultural Studies of Science Education, 15(2), 433-452. https://doi.org/10.1007/s11422-019-09934-x

Donaldson, M. (1978). Children's minds. Fontana.

Driver, R., \& Easley, J. A. (1978). Pupils and paradigms: A review of literature related to concept development in adolescent science students. Studies in Science Education, 5, 61-84. https://doi.org/10.1080/03057267808559857

Duit, R. (2009). Bibliography - Students' and Teachers' Conceptions and Science education. http://www.ipn.unikiel.de/aktuell/stcse/stcse

Fleer, M. (2009). Understanding the dialectical relations between everyday concepts and scientific concepts within play-based programs. Research in Science Education, 39, 281-306. https://doi.org/10.1007/s11165-008-9085-x

Fleer, M., \& Pramling, N. (Eds) (2015). Knowledge construction in early childhood science education. In A cultural-historical study of children learning science (pp. 67-93). Springer https://doi.org/10.1007/978-94-017-9370-4 5

Golumbia, D. (2015). The language of science and the science of language: Chomsky's Cartesianism. Diacritics, 43(1), 38-62. https://doi.org/10.1353/dia.2015.0004

Gomes, J., \& Fleer, M. (2018). Is science really everywhere? Teachers' perspectives on science learning possibilities in the preschool environment. Research in Science Education, 50(5), 1961-1989. https://doi.org/10.1007/s11165-018-9760-5

Güneş, G., \& Şahin, V. (2020). Preschoolers' thoughts on the concept of time. The Journal of Genetic Psychology, 181(4), $293-317$. https://doi.org/10.1080/00221325.2020.1753645

Häikklä, M., \& Sahlström, F. (2003). Om användning av videoinspelning i fältarbete. [On the use of video recording in field work] Pedagogisk forskning i Sverige, 8(1-2), 24-41.

Hobson, S., Trundle, K., \& Saçkes, M. (2010). Using a Planetarium software program to promote conceptual change with young children. Journal of Science Education and Technology, 19(2), 165-176. https://doi.org/10.1007/s10956-009-9189-8

Hundeide, K. (1977). Piaget $i$ kritisk lys. [Piaget in a critical light] Cappelen.

Kalogiannakis, M., Nirgianaki, G.-M., \& Papadakis, St. (2018). Teaching magnetism to preschool children: the effectiveness of picture story reading. Early Childhood Education Journal, 46(5), 535-546. https://doi.org/10.1007/s10643-017-0884-4

Lewis, G., Jones, B., \& Baker, C. (2012). Translanguaging: Developing its conceptualisation and contextualisation. Educational Research and Evaluation, 18(7), 655-670. https://doi.org/10.1080/13803611.2012.718490

Lgr11. (2018). Curriculum for the compulsory school, preschool class and school-age educare (revised 2018). National Agency for Education. https://www.skolverket.se/publikationer?id=3984

Lpfö 18. (2018). Curriculum for the preschool. National Agency for Education. https://www.skolverket.se/download/18.6bfaca41169863e6a65d5aa/1553968116077/pdf4001.pdf

Mawson, B. (2010). Children's developing understanding of technology. International Journal of Technology and Design Education, 20(1), 1-13. https://doi.org/10.1007/s10798-008-9062-8

Milne, L., \& Edwards, R. (2011). Young children's views of the technological process: an exploratory study. International Journal of Technology and Design Education, 23, 11-21. https://doi.org/10.1007/s10798-011-9169-1

Nordén, B., \& Avery, H. (2020). Redesign of an outdoor space in a Swedish preschool: Opportunities and constraints for sustainability education. International Journal of Early Childhood, 52(3), 319-335. https://doi.org/10.1007/s13158-020-00275-3

Ødegaard, M. (2003). Dramatic science. A critical review of drama in science education. Studies in Science Education, 39(1), 75-101. https://doi.org/10.1080/03057260308560196

Osborne, R., \& Freyberg, P. (1985). Learning in Science. The Implications of Children's Science. Heinemann Educational Books.

Piaget, J. (1969). The child's conception of time. (AJ Pomerans Trans.). Routledge \& Kegan Paul. (Original work published 1946).

Piaget, J. (1971). The language and thought of the child. (M. \& R. Gabain Trans.) Routledge \& Kegan Paul. (Original work published 1929).

Piaget, J. (1973). The child's conception of the world. (J. \& A. Tomlinson Trans.) Paladin. (Original work published 1923).

Pramling, N. (2006). 'The clouds are alive because they fly in the air as if they were birds': A re-analysis of what children say and mean in clinical interviews in the work of Jean Piaget. European Journal of Psychology of Education, 21(4), 453-466. https://doi.org/10.1007/BF03173514

Pramling, N. (2015). The nature of scientific educational encounters. In M. Fleer and N. Pramling (Ed.) A cultural-historical study of children learning science (pp. 179-195). Springer. https://doi.org/10.1007/978-94-017-9370-4 11

Pramling, N., \& Pramling Samuelsson, I. (Eds)(2011). Educational encounters: Nordic studies in early childhood didactics (International perspectives on early childhood education and development, v. 4). Springer. https://doi.org/10.1007/978-94-007-1617-9 
Robbins, J. (2005). 'Brown paper packages'? A sociocultural perspective on young children's ideas in science. Research in Science Education, 35, 151-172. https://doi.org/10.1007/s11165-005-0092-x

Rogers, A., \& Russo, S. (2003). Blocks: A commonly encountered play activity in the early years, or a key to facilitating skills in science, maths and technology. Investigating, 19(1), 17-20.

Saçkes, M. (2014). How often do early childhood teachers teach science concepts? Determinants of the frequency of science teaching in kindergarten. European early childhood education research journal, 22(2), 169-184. https://doi.org/10.1080/1350293X.2012.704305

Saçkes, M. (2015a). Young children's ideas about earth and space science concepts. In K. Trundle and M. Saçkes (Eds.), Research in early childhood science education (pp. 35-65). Springer. https://doi.org/10.1007/978-94-017-9505-0 3

Saçkes, M. (2015b). Kindergartners' mental models of the day and night cycle: Implications for instructional practices in earlychildhood classrooms. Kuram ve Uygulamada Eğitim Bilimleri Dergisi, 15(4), 997-1006.

Saçkes, M., Flevares, L., \& Trundle, K. C. (2010). Four- to six-year-old children's conceptions of the mechanism of rainfall. Early Childhood Research Quarterly, 25(4), 536-546. https://doi.org/10.1016/j.ecresq.2010.01.001

Saçkes, M., Trundle, K., Bell, R., \& O'Connell, A. (2011). The influence of early science experience in kindergarten on children's immediate and later science achievement: Evidence from the early childhood longitudinal study. Journal of Research in Science Teaching, 48(2), 217-235. https://doi.org/10.1002/tea.20395

Sherif, V. (2018). Evaluating preexisting qualitative research data for secondary analysis. Forum, Qualitative Social Research, 19(2), art 7 https://doi.org/10.17169/fqs-19.2.2821

Siry, C. \& Gorges, A. (2020). Young students' diverse resources for meaning making in science: Learning from multilingual contexts. International Journal of Science Education, 42(14), 2364-2386. https://doi.org/10.1080/09500693.2019.1625495

Siry, C. (2011). Exploring the significance of resource-rich views in science education. Cultural Studies of Science Education, 6(4), 10191029. https://doi.org/10.1007/s11422-011-9353-3

Siry, C. (2013). Exploring the complexities of children's inquiries in science: Knowledge production through participatory practices. Research in Science Education, 43(6), 2407-2430. https://doi.org/10.1007/s11165-013-9364-z

Siry, C., \& Kremer, I. (2011). Children explain the rainbow: Using young children's ideas to guide science curricula. Journal of Science Education and Technology, 20(5), 643-655. https://doi.org/10.1007/s10956-011-9320-5

Smith, E. (2008). Pitfalls and promises: The use of secondary data analysis in educational research. British Journal of Educational Studies, 56(3), 323-339. https://doi.org/10.1111/j.1467-8527.2008.00405.x

Sundberg, B., Areljung, S., Due, K., Ekström, K., Ottander, C., \& Tellgren, B. (2018). Opportunities for and obstacles to science in preschools: Views from a community perspective. International Journal of Science Education, 40(17), 2061-2077. https://doi.org/10.1080/09500693.2018.1518615

Thorshag, K. (2019). Barns teknikskapande: en studie av bygg-och konstruktionslek i förskolan [Children's technology creation. A study of building- and construction play in preschool.] (Doctoral dissertation). Malmö universitet.

Tu, T. (2006). Preschool science environment: What is available in a preschool classroom?. Early Childhood Education Journal, 33(4), 245251. https://doi.org/10.1007/s10643-005-0049-8

Veresov, N. (2004) Vygotsky before Vygotsky: The Path to the Cultural-historical Theory of Human Consciousness (1917-1927): Historical and Methodological Analysis. 1998. Print. Acta Universitatis Ouluensis Ser. E, Scientiae Rerum Socialium, 30.

Vosniadou, S. (1994). Capturing and modeling the process of conceptual change. Learning and Instruction, 4,(1) 45-69. https://doi.org/10.1016/0959-4752(94)90018-3

Vygotsky, L. S. (1987). Thinking and speech. In R. W. Rieber and A. S. Carton (Eds.) The collected works of L.S. Vygotsky. Vol. 1. Problems of general psychology, 39- 285. (N. Minick, Trans.). Plenum. (Original work published 1934)

Vygotsky, L. S. (1999). Tänkande och språk [Thinking and speech] (K. Öberg Lindsten, Trans.) Daidalos. (Original work published 1934)

Vygotsky, L.S. (1995). Fantasi och kreativitet I barndomen [Fantasy and creativity in childhood] (K. Öberg Lindsten, Trans.). Daidalos. (Original work published 1930)

Vygotsky, L.S. (1998). Child psychology. In R. W. Rieber and A. S. Carton (Eds.) The collected works of L.S. Vygotsky. Vol. 5. (M. J. Hall, Trans.). Plenum. (Original work published 1935)

Wittgenstein, L. (1968). Philosophical investigations (3 ${ }^{\text {rd }}$ ed). (G. E. M. Anscombe, Trans.) Basil Blackwell. (Original work published 1953) 